\title{
23. LATE EOCENE TO OLIGOCENE BENTHIC FORAMINIFERAL ISOTOPIC RECORD, SITE 574, EQUATORIAL PACIFIC ${ }^{1}$
}

\author{
Kenneth G. Miller, Lamont-Doherty Geological Observatory, Columbia University \\ and \\ Ellen Thomas, Scripps Institution of Oceanography, University of California, San Diego ${ }^{2}$
}

\begin{abstract}
Oxygen and carbon isotopic data from mixed species of the benthic foraminifer Cibicidoides at Site 574 in the equatorial Pacific are compared with benthic foraminiferal isotopic data from equatorial Pacific Site 77 (Keigwin and Keller, 1984) and western North Atlantic Site 563 (Miller and Fairbanks, 1983, in press). Cibicidoides within the age range of $\sim 33$ to $35 \mathrm{Ma}$ (within the early Oligocene) at the Pacific sites were lower in $\delta^{13} \mathrm{C}$ than those of the same age from the North Atlantic site. For those from $\sim 26$ to $33 \mathrm{Ma}$ (late early to late Oligocene), the equatorial Pacific and western North Atlantic $\delta^{13} \mathrm{C}$ values were similar, whereas for those from $\sim 26$ to $12 \mathrm{Ma}$ (latest Oligocene to Miocene) (see Miller and Fairbanks, 1983), Pacific values were lower. We suggest that this reflects bottom-water production analogous to modern North Atlantic Deep Water (NADW) in the early Oligocene and latest Oligocene to Miocene and reduced production of "NADW" in the late early to late Oligocene. High $\delta^{18} \mathrm{O}$ values (approximately $2.0 \%$ ) were recorded at Site 574 for Cibicidoides at $36 \mathrm{Ma}$ (earliest Oligocene); high, oscillating $\delta^{18} \mathrm{O}$ values occurred from 30 to $29 \mathrm{Ma}$ (near the early/late Oligocene boundary). These intervals of high $\delta^{18} \mathrm{O}$ values apparently represent either bottom waters colder than at present or the presence of significant continental ice sheets. We suggest that major periods of continental glaciation occurred at approximately 36 and from 29 to $30 \mathrm{Ma}$.
\end{abstract}

\section{INTRODUCTION}

Isotopic studies of Tertiary benthic foraminifers have emphasized $\delta^{18} \mathrm{O}$ history and have used these records as indicators of past ice volume (hence sea level) and bottom-water temperatures (Shackleton and Kennett, 1975; Savin et al., 1975, 1981; Savin, 1977; Woodruff et al., 1981). Although carbon isotopic records have been used successfully in stratigraphy (e.g., Keigwin, 1979; Vincent et al., 1980; Haq et al., 1980; Savin et al., 1981), their utility as paleoenvironmental indicators has been hindered by the numerous possible interpretations of the relatively small variations in the $\delta^{13} \mathrm{C}$ records of deep and bottom waters (Berger et al., 1981). Deep-water benthic foraminiferal $\delta^{13} \mathrm{C}$ variations may be due to either global changes in the ${ }^{13} \mathrm{C}$ budget (Shackleton, 1977; Broecker, 1982) or changes in abyssal circulation. (Kroopnick et al., 1972; Kroopnick, 1974, 1980; Bender and Keigwin, 1979; Belanger et al., 1981; Curry and Lohmann, 1982, 1983). Most studies of North Atlantic Tertiary $\delta^{13} \mathrm{C}$ records have been restricted to bathyal locations, and therefore may only represent changes in intermediate water (Blanc et al., 1980; Blanc and Duplessy, 1982). Tertiary carbon isotopic comparisons also have been hampered by most data being based on analyses of benthic assemblages or taxa (such as Oridorsalis spp.) that do not accurately record modern deep-sea $\delta^{13} \mathrm{C}$ distributions (Belanger et al., 1981).

Curry and Lohmann $(1982,1983)$ isolated abyssal circulation changes from global $\delta^{13} \mathrm{C}$ changes for the late

\footnotetext{
${ }^{1}$ Mayer, L., Theyer, F., et al., Init. Repts. DSDP, 85: Washington (U.S. Govt. Printing Office).

Addresses: (Miller; and Thomas, present address) Lamont-Doherty Geological Observatory, Columbia University, Palisades, NY 10964.
}

Quaternary by examining synoptic benthic foraminiferal $\delta^{13} \mathrm{C}$ records over a wide bathymetric range from a small geographic region. Such core coverage is lacking in the Tertiary, but it is possible to make comparisons of $\delta^{13} \mathrm{C}$ from different ocean basins to isolate global changes from abyssal circulation changes. This method assumes that the records compared are representative of bottom-water $\delta^{13} \mathrm{C}$ conditions for the basins examined.

Miller and Fairbanks (1983) noted three cycles in the Oligocene to middle Miocene benthic foraminiferal $\delta^{13} \mathrm{C}$ record. These cycles were observed in benthic foraminifers from the North Atlantic (Miller and Curry, 1982; Miller and Fairbanks, 1983, in press), the South Atlantic (Poore and Matthews, 1984; Shackleton et al., 1984), and the Pacific (Savin et al., 1981; Keigwin and Keller, 1984). They were also observed in planktonic foraminifers (Shackleton et al., in press; Miller and Fairbanks, in press), suggesting that these $\delta^{13} \mathrm{C}$ cycles resulted from global changes in the ${ }^{13} \mathrm{C}$ budget (Miller and Fairbanks, 1983 , in press).

Synoptic offsets in $\delta^{13} \mathrm{C}$ between basins can be used to infer abyssal circulation. The interpretations of such interbasinal comparisons are based on analogy with the modern ocean. Today, basin-basin fractionation (Berger, 1970) results in Pacific bottom water having $\delta^{13} \mathrm{C}$ values lower by approximately $1.0 \%$ than Atlantic bottom water, which is influenced by production of young, ${ }^{13} \mathrm{C}$-enriched North Atlantic Deep Water (NADW) (Kroopnick et al., 1972; Kroopnick, 1974, 1980). Miller and Fairbanks (1983) measured an offset between Atlantic and Pacific benthic foraminiferal $\delta^{13} \mathrm{C}$ records from the latest Oligocene $(\sim 26 \mathrm{Ma})$ to middle Miocene $(\sim 12$ $\mathrm{Ma}$ ) that was similar to the modern offset. They concluded that the production of bottom water analogous to modern NADW began prior to the latest Oligocene. 
They could not extend their comparison further back in time because of a lack of suitable data from the Oligocene of the Pacific.

We attempt to isolate the Oligocene global $\delta^{13} \mathrm{C}$ signal from abyssal circulation $\delta^{13} \mathrm{C}$ changes by making interbasinal (North Atlantic versus Pacific) comparisons of $\delta^{13} \mathrm{C}$ records. Oligocene oxygen and carbon isotopic data from Site 574 in the equatorial Pacific $\left(03^{\circ} 59.24^{\prime} \mathrm{N}\right.$, $114^{\circ} 8.53^{\prime} \mathrm{W}$; $4561 \mathrm{~m}$ present water depth; this study) are compared with records from Site 77 in the equatorial Pacific $\left(00^{\circ} 28.90^{\prime} \mathrm{N}, 133^{\circ} 13.70^{\prime} \mathrm{W} ; 4291 \mathrm{~m}\right.$ present water depth; Keigwin and Keller, 1984) and Site 563 in the western North Atlantic $\left(33^{\circ} 38.53^{\prime} \mathrm{N}, 43^{\circ} 46.04^{\prime} \mathrm{W}\right.$; $3496 \mathrm{~m}$ present water depth; Miller and Fairbanks, 1983). These comparisons demonstrate that higher $\delta^{13} \mathrm{C}$ values occurred at the Atlantic site from 33 to $35 \mathrm{Ma}$ (within the early Oligocene) and from 26 to $12 \mathrm{Ma}$ (latest Oligocene to Miocene) (Miller and Fairbanks, 1983). However, $\delta^{13} \mathrm{C}$ values were similar (with variations being $<0.3 \%$ ) at all three locations between about 26 and $33 \mathrm{Ma}$ (late early to late Oligocene).

\section{METHODS}

Isotopic analyses were performed on mixed species of the benthic foraminiferal taxon Cibicidoides. This taxon secretes calcite tests that have a constant offset from $\delta^{18} \mathrm{O}$ equilibrium equal to $0.65 \% 0$ (Shackleton and Opdyke, 1973; Duplessy et al., 1980; Woodruff et al., 1980; Belanger et al., 1981; Graham et al., 1981). Studies of Holocene core tops demonstrated that Cibicidoides accurately reflects the distribution of $\delta^{13} \mathrm{C}$ of $\Sigma^{2} \mathrm{CO}_{2}$ in the modern ocean (Belanger et al., 1981; Graham et al., 1981).

Samples were washed with sodium hexametaphosphate and/or hydrogen peroxide in tap water through a $63 \mu \mathrm{m}$ sieve and air dried. Specimens for isotopic analyses were ultrasonically cleaned in distilled water for 10 to $20 \mathrm{~s}$, crushed, and roasted at $370^{\circ} \mathrm{C}$ in a vacuum to remove organic matter. The $\mathrm{CaCO}_{3}$ was reacted with $\mathrm{H}_{3} \mathrm{PO}_{4}$ at $50^{\circ} \mathrm{C}$, and the gas was analyzed on a VG Micromass 903E mass spectrometer at Lamont-Doherty Geological Observatory (see Table 1; Fig. 1). Ages are reported using the Berggren et al. (in press) time scale by interpolation between datum levels (see Figs. 2 and 3).

Sites 574,77 , and 563 were located at abyssal depths (greater than $2000 \mathrm{~m}$ ) during the Oligocene. Site $563 \mathrm{can}$ be "backtracked" (Sclater et al., 1971; Berger and Winterer, 1974; Sclater et al., 1977; Parsons and Sclater, 1977) using the empirical western North Atlantic age versus subsidence curve (Tucholke and Vogt, 1979) to about $2200 \mathrm{~m}$ during the earliest Oligocene (36 Ma) and $3100 \mathrm{~m}$ during the latest Oligocene ( $24 \mathrm{Ma}$ ). Backtrack estimates are 3200 and $2700 \mathrm{~m}$ during the earliest Oligocene (36 Ma) and 3900 and $3600 \mathrm{~m}$ during the latest Oligocene (24 Ma) for Sites 574 and 77, respectively (using the empirical Pacific age-subsidence curve of Sclater et al., 1977).

\section{RESULTS AND DISCUSSION}

We sampled approximately one sample per core (29 samples); thus, for the 14 m.y. interval studied, our av- erage sampling interval is approximately $0.5 \mathrm{~m} . \mathrm{y}$. If highfrequency changes similar to those of the Quaternary are present (on the order of $10^{4}$ to $10^{5} \mathrm{yr}$.), our sampling would introduce aliasing. However, the oxygen and carbon isotopic records from Site 574 (Fig. 1) show patterns and magnitudes that are remarkably similar to records from Site 77 (Fig. 2) (Keigwin and Keller, 1984). This consistency exists between sites with different sampling intervals (Fig. 2). Thus, we believe that our sampling interval is sufficient to resolve isotopic changes on the order of $10^{6}$ to $10^{7} \mathrm{yr}$.

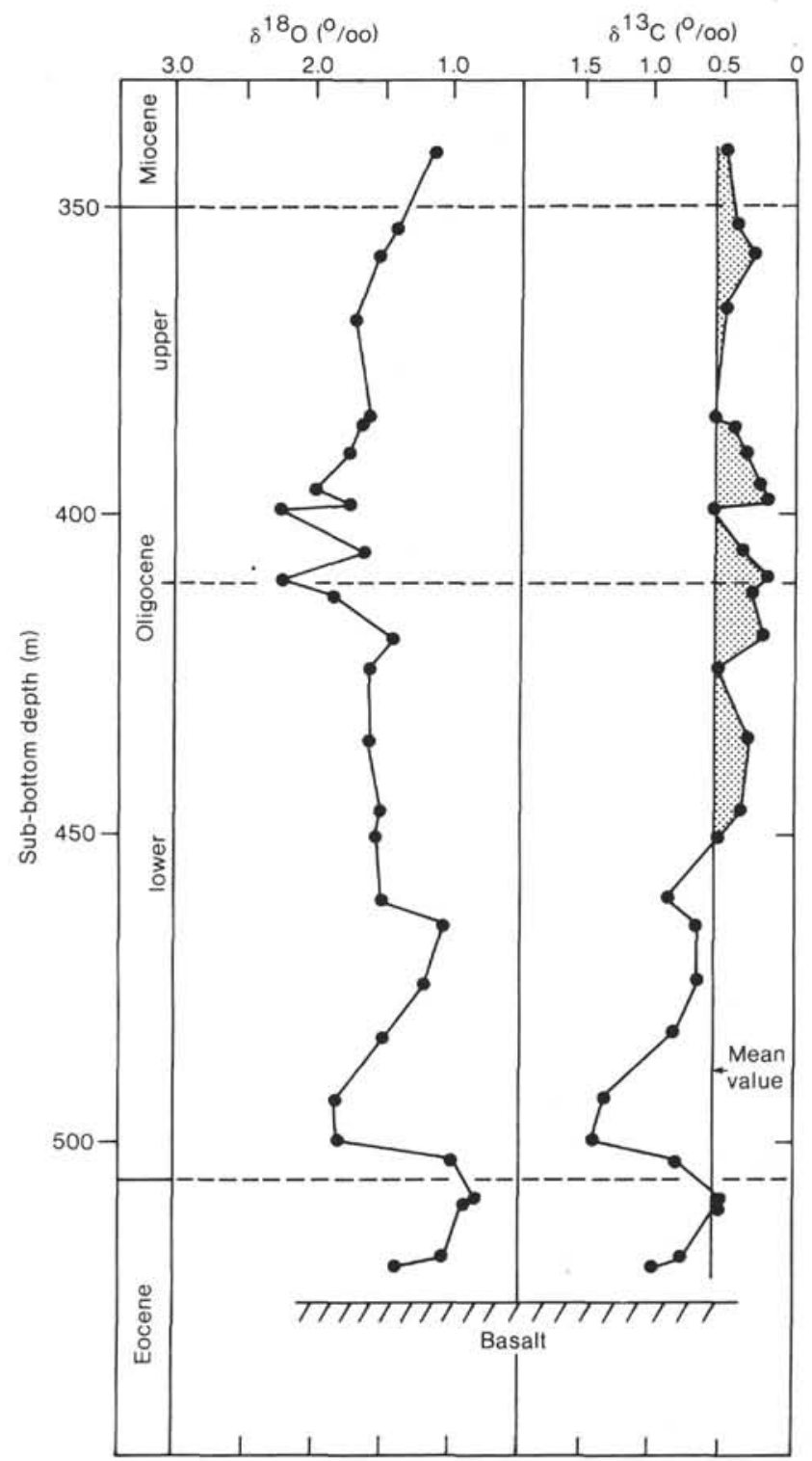

Figure 1. Oxygen and carbon isotopic values for the benthic foraminiferal taxon Cibicidoides at Site 574. Vertical line on left indicates the mean of ${ }^{13} \mathrm{C}$ values at $0.6 \%$ (see Table 1); depleted intervals are indicated with stipples. The Eocene/Oligocene boundary is drawn at the last occurrence of Nuttallides truempyi, although nannofossils suggest that it may be above this by $\sim 2 \mathrm{~m}$; the lower/middle Oligocene boundary is drawn on the basis of estimates from interpolation of sedimentation rates. 


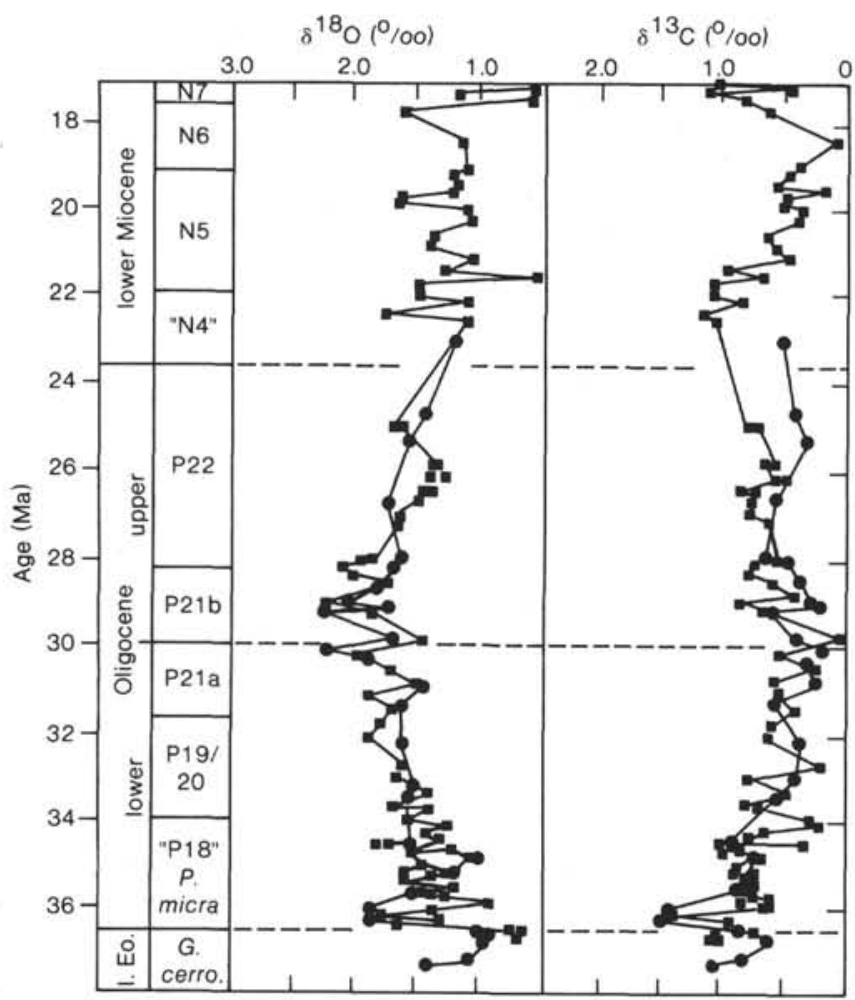

Figure 2. Age comparison of the records of Site 574 (dots) and Site 77 (squares). Site 77 data: Oligocene, after Keigwin and Keller (1984); Miocene, after Savin et al. (1981). Age assignments for Site 77 obtained by interpolating between the following datum levels: first occurrence (FO), Praeorbulina, $241 \mathrm{~m}$ sub-bottom, 16.6 Ma; FO, G. kugleri, $317 \mathrm{~m}, 23.6 \mathrm{Ma}$; last occurrence (LO), Chiloguembeli$n a, 375 \mathrm{~m}, 30.0 \mathrm{Ma}$; LO, Pseudohastigerina, $413.5 \mathrm{~m}, 34.0 \mathrm{Ma}$; oxygen isotopic enrichment, $470 \mathrm{~m}, 36.4 \mathrm{Ma}$. Biostratigraphic datum levels after Keller (1981) and Hays et al. (1972). Age assignments for Site 574 after Site 574 chapter, this volume.

It is possible for diagenesis to alter the original isotopic record in such cases as this (e.g., Arthur et al., 1979; Miller and Curry, 1982; Killingley, 1983). However, this appears not to have occurred here. The close agreement between the $\delta^{18} \mathrm{O}$ records at Site 574 and 77 (Fig. 2) occurs at sites with different burial depths (corresponding sections at Site 574 are approximately $50 \mathrm{~m}$ deeper). In addition, the oxygen values noted at these sites are similar to Oligocene values reported elsewhere (Keigwin, 1980; Miller and Curry, 1982; Poore and Matthews, 1984; Belanger and Matthews, in press; Shackleton et al., 1984). The correspondence of $\delta^{18} \mathrm{O}$ values among sites with a wide range of burial depths and preservational states suggests that the records have not been altered significantly by diagenesis.

\section{Oxygen Isotopes}

The $\delta^{18} \mathrm{O}$ record at Site 574 shows a major increase ( $\sim 0.9 \%$ between 503 and $500 \mathrm{~m}$ sub-bottom depth) just above the Eocene/Oligocene boundary $(\sim 504-506 \mathrm{~m})$ (Fig. 1). Keigwin (1980), Snyder et al. (1984), and Miller, Curry, et al. (in press) demonstrated that a similar increase at Sites 277 (Southern Ocean), 289 (Pacific), and 549 (northeastern North Atlantic) occurred immediately following the extinction of planktonic foraminifers used to recognize the Eocene/Oligocene boundary (i.e., Hantkenina spp. and Globorotalia cerroazulensis cerroazulensis) and also occurred within Zone NP21. Thus, if the extinctions were synchronous, then the previously reported enrichments should correlate in time (Miller, Curry, et al., in press). The best estimate for the timing of this enrichment is in the middle of Zone NP21 at approximately $36 \pm 0.5 \mathrm{Ma}$ (time scale of Berggren et al., in press); this is in good agreement with the estimate obtained at Site $574(36.4 \mathrm{Ma})$ by interpolation of sedimentation rates. Such interpolations suggest that the oxygen isotopic enrichment between 500 and $503 \mathrm{~m}$ sub-bottom at Site 574 occurred in less than a 0.2-m.y interval.

At Site 574 , the $\delta^{18} \mathrm{O}$ increase occurred immediately after the last occurrence (LO) of Nuttallides truempyi (LO, Sample 33-5, 141-143 cm; $506 \mathrm{~m}$ sub-bottom (Thomas, this volume). The $\delta^{18} \mathrm{O}$ increase also postdated the LO of Discoaster saipanensis (namely, within Zone NP21; LO, between Sample 33-5, 5-7 cm, $504.14 \mathrm{~m}$ sub-bottom and Sample 33-4, 114-116 cm, $504.55 \mathrm{~m}$ sub-bottom). D. barbadiensis has its LO between 574C-34-2, $93 \mathrm{~cm}$ and 574C-34-2, $60 \mathrm{~cm}$ (Barron et al., this volume). $N$. truempyi apparently became extinct at the end of the Eocene (Tjalsma and Lohmann, 1983; Wood et al., in press), suggesting that the increase occurred in the earliest Oligocene. This is consistent with the assignment of the increase to Zone NP21 because this zone straddles the Eocene/Oligocene boundary (Snyder et al., 1984; Miller, Curry, et al., in press).

At Site 77, a similar $\delta^{18} \mathrm{O}$ increase was noted (Keigwin and Keller, 1984); this enrichment also occurred just following the extinction of $D$. saipanensis and $D$. barbadiensis, namely, within Zone NP21 (Hays et al., 1972). Unfortunately, diagnostic planktonic foraminifers are missing from the uppermost Eocene to lowermost Oligocene sections at Site 77 due to dissolution, and precise biostratigraphic correlation (with resolution better than 1 m.y.) is therefore lacking. Because of this, we constrained our age model for Site 77 to the interval from 34 to $36 \mathrm{Ma}$ (Fig. 2) using the earliest Oligocene oxygen isotopic enrichment as an interpolation point.

Magnetostratigraphic data are needed to establish firstorder magnetostratigraphic, biostratigraphic, and isotopic correlations and the isochrony of the earliest Oligocene $\delta^{18} \mathrm{O}$ increase. Our biostratigraphic and isotopic correlations suggest that the increase should correlate with the reversed interval of Chron $\mathrm{C} 13$ (i.e., between Anomalies 13 and 15) (chron terminology of LaBrecque et al., 1983; see also Barron et al., this volume). The only primary correlation has been made at Site 522 (Poore and Matthews, 1984; Oberhänsli et al., 1984), and is limited by sample resolution. At Site 522, the enrichment could have occurred either in the normal interval of Chron C13 (i.e., 35.3 to $35.9 \mathrm{Ma}$ ) or immediately before it.

Oxygen isotopic values at Site 574 are relatively constant between 424 and $465 \mathrm{~m}$ sub-bottom (lower Oligocene) (Fig. 1; Table 1). A $\delta^{18} \mathrm{O}$ increase and associated series of oscillations occurs between 419 and 389 m near the lower/middle Oligocene boundary in the upper part of Zone NP23 to Zone NP24 and in Zone P21 to lower Zone P22 (Site 574 chapter, this volume). This increase 
biostratigraphically correlates with a similar $\delta^{18} \mathrm{O}$ change noted at Site 77 in Zone P21 (Fig. 2) (Keigwin and Keller, 1984). Values in the interval from $\sim 30$ to $29 \mathrm{Ma}$ ("middle" Oligocene) at Sites 574 and 77 are higher than those noted in the lower Oligocene section; some values exceed $2.0 \%$ (Table 1). Oxygen isotopic values subsequently decrease in the uppermost Oligocene section. Resolution in the uppermost Oligocene at both sites is limited at present.

A comparison (Fig. 3) of the isotopic records at western North Atlantic Site 563 (Miller and Fairbanks, 1983) with Sites 574 and 77 shows that the "middle" Oligocene $\delta^{18} \mathrm{O}$ increase is absent at Site 563. However, magnetobiostratigraphic comparisons (Miller, Aubry, et al., in press) show that the "middle" Oligocene at Site 563 is condensed or missing, specifically Chron C8R and perhaps portions of Chrons $\mathrm{C} 10$ and $\mathrm{C} 11$ are missing (chron terms of Berggren et al., in press).

\section{Carbon Isotopes}

The carbon isotopic record at Site 574 shows an enrichment in the lowermost Oligocene at the same level as the ${ }^{18} \mathrm{O}$ enrichment; a similar enrichment was noted at Site 77 (Fig. 2) (Keller and Keigwin, 1984). Between 461 and $499 \mathrm{~m}$ sub-bottom (lower lower Oligocene), $\delta^{13} \mathrm{C}$ values are high $(>0.6 \% 0)$ compared with values between 451 and $341 \mathrm{~m}$ sub-bottom (upper lower and upper Oligocene), which are less than $0.7 \% 0$ (Fig. 1). This pattern of decreasing $\delta^{13} \mathrm{C}$ in benthic foraminifers from early to late Oligocene was noted at Site 77 (Keigwin and Keller, 1984), Site 563 (Miller and Fairbanks, 1983), South At-

Table 1. Oxygen and carbon isotopic values for mixed species of Cibicidoides, Site 574 (reported to PDB standard).

\begin{tabular}{|c|c|c|c|c|}
\hline $\begin{array}{l}\text { Sample } \\
\text { (interval in } \mathrm{cm} \text { ) }\end{array}$ & $\begin{array}{l}\text { Sub-bottom } \\
\text { depth } \\
\text { (m) }\end{array}$ & $\begin{array}{l}\text { Age } \\
\text { (Ma) }\end{array}$ & $\begin{array}{l}\delta^{18} \mathrm{O} \\
(\% 0)\end{array}$ & $\begin{array}{l}\delta^{13} \mathrm{C} \\
(\% 0)\end{array}$ \\
\hline $16, \mathrm{CC}$ & $341.88 \mathrm{~m}$ & 23.0 & 1.15 & 0.49 \\
\hline $17, \mathrm{CC}$ & 353.97 & 24.7 & 1.46 & 0.40 \\
\hline $18, \mathrm{CC}$ & 358.48 & 25.3 & 1.54 & 0.28 \\
\hline $19, \mathrm{CC}$ & 368.17 & 26.7 & 1.71 & 0.55 \\
\hline $20, \mathrm{CC}$ & 384.25 & 28.0 & 1.61 & 0.62 \\
\hline $21-1,79-81$ & 385.29 & 28.1 & 1.67 & 0.43 \\
\hline $21-4,88-93$ & 389.88 & 28.5 & 1.75 & 0.35 \\
\hline $22-2,47-53$ & 395.97 & 29.0 & 2.01 & 0.24 \\
\hline $22-3,125-130$ & 398.20 & 29.1 & 1.73 & 0.17 \\
\hline $22, \mathrm{CC}$ & 398.87 & 29.2 & 2.27 & 0.60 \\
\hline $23-2,96-101$ & 405.96 & 29.8 & 1.65 & 0.38 \\
\hline $23-5,87-92$ & 410.37 & 30.1 & 2.23 & 0.18 \\
\hline $23, \mathrm{CC}$ & 412.47 & 30.3 & 1.87 & 0.31 \\
\hline $24, \mathrm{CC}$ & 419.47 & 30.9 & 1.43 & 0.21 \\
\hline $25, \mathrm{CC}$ & 424.51 & 31.3 & 1.61 & 0.56 \\
\hline $26, \mathrm{CC}$ & 435.90 & 32.2 & 1.61 & 0.34 \\
\hline $27, \mathrm{CC}$ & 446.86 & 33.1 & 1.51 & 0.40 \\
\hline $28, \mathrm{CC}$ & 451.57 & 33.5 & 1.55 & 0.56 \\
\hline $29-1,80-83$ & 461.32 & 34.5 & 1.53 & 0.94 \\
\hline $29, \mathrm{CC}$ & 465.27 & 34.8 & 1.05 & 0.71 \\
\hline $30, \mathrm{CC}$ & 474.85 & 35.2 & 1.19 & 0.72 \\
\hline $31, \mathrm{CC}$ & 483.15 & 35.6 & 1.51 & 0.90 \\
\hline $32, \mathrm{CC}$ & 493.19 & 36.0 & 1.86 & 1.40 \\
\hline $33-1,113-115$ & 499.64 & 36.3 & 1.84 & 1.48 \\
\hline $33-3,113-115$ & 502.64 & 36.5 & 0.99 & 0.89 \\
\hline $34-1,71-73$ & 508.72 & 36.7 & 0.83 & 0.57 \\
\hline $34-2,25-27$ & 509.76 & 36.8 & 0.96 & 0.58 \\
\hline $35-1,97-98$ & 518.48 & 37.2 & 1.05 & 0.83 \\
\hline $35-2,99-100$ & 520.00 & 37.3 & 1.41 & 1.06 \\
\hline
\end{tabular}

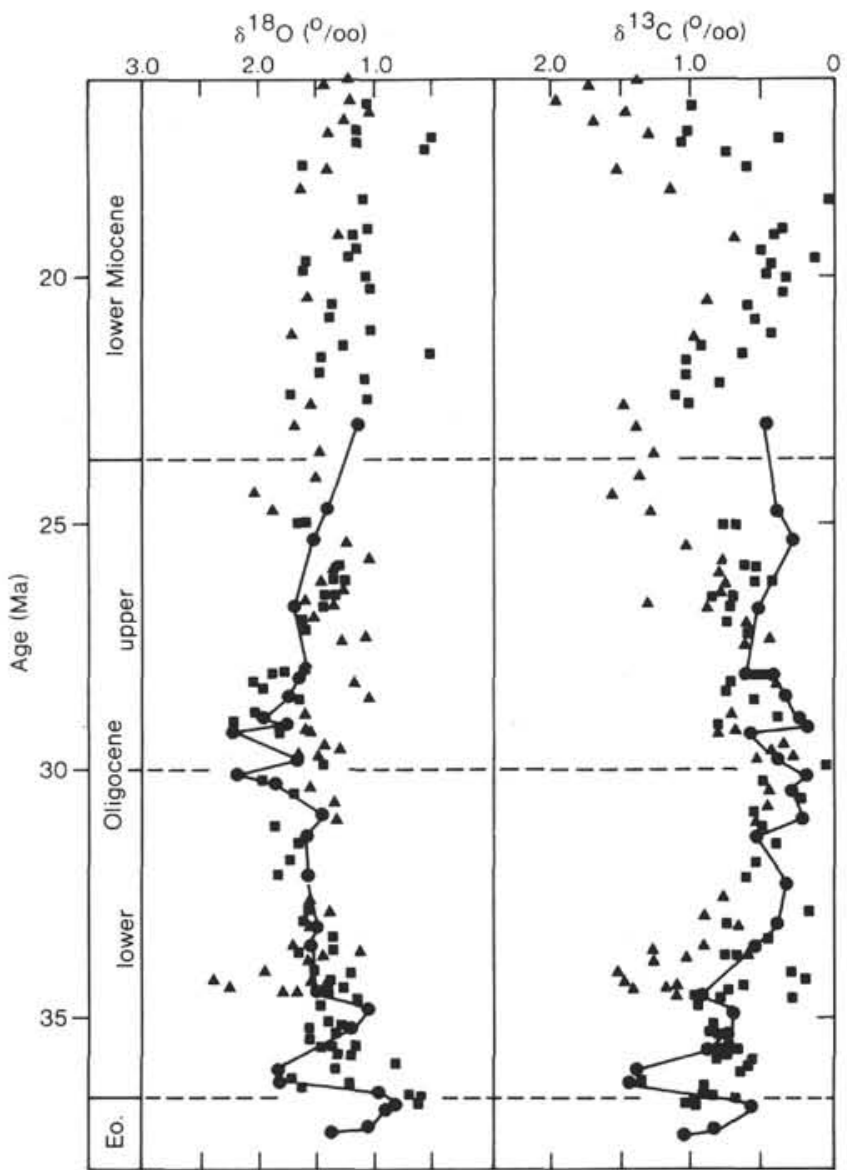

Figure 3. Comparison of $\delta^{18} \mathrm{O}$ and $\delta^{13} \mathrm{C}$ values for Cibicidoides at western North Atlantic Site 563 (triangles), Pacific Site 574 (dots), and Pacific Site 77 (squares). Age assignments for Site 563 based on interpolation and extrapolation of sedimentation rates between the following datum levels: top of Chron C5DN, $260.0 \mathrm{~m}$ sub-bottom, 17.57 Ma; base of Chron C5DN, $267.0 \mathrm{~m}, 18.14 \mathrm{Ma}$; unconformity $270.5 \mathrm{~m}$ at $18.42-19.41 \mathrm{Ma}$; base of Chron C6N, $277.5 \mathrm{~m}$, 20.45 Ma; top of Chron C6CN, 296.5 m, 23.27 Ma; LO, Chiloguembelina, $326.0 \mathrm{~m}, 30.0 \mathrm{Ma}$; base of Chron $\mathrm{C} 12 \mathrm{~N}, 339.0 \mathrm{~m}$, $32.9 \mathrm{Ma}$; LO, Pseudohastigerina, $353.5 \mathrm{~m}, 34.0 \mathrm{Ma}$.

lantic Site 522 (Poore and Matthews, 1984), Leg 74 (South Atlantic) sites (Shackleton et al., 1984), Gulf of Mexico Site 540 (Belanger and Matthews, in press), and Sites 119 and 400 in the Bay of Biscay (Miller and Curry, 1982). In addition, this $\delta^{13} \mathrm{C}$ change has been noted in planktonic foraminifers (Shackleton et al., 1984; Miller and Fairbanks, in press), implying that the decrease resulted from a change in the global ${ }^{13} \mathrm{C}$ budget.

Comparison of western North Atlantic (Site 563) and Pacific (Sites 574 and 77) $\delta^{13} \mathrm{C}$ records shows that the $\mathrm{Pa}$ cific sites were depleted in ${ }^{13} \mathrm{C}$ from about 33 to $35 \mathrm{Ma}$ (early Oligocene) and from 18 to $26 \mathrm{Ma}$ (latest Oligocene to Miocene). However, there appears to have been little difference between the Atlantic and the Pacific sites from about 26 to $33 \mathrm{Ma}$ (late early to late Oligocene). Our interpretation of the carbon isotopic record is that in the early Oligocene and latest Oligocene to Miocene, nutrient-depleted, ${ }^{13} \mathrm{C}$-enriched bottom waters formed in the North Atlantic and/or its marginal seas. This circulation pattern resulted in ${ }^{13} \mathrm{C}$-enriched bottom waters 
in the western North Atlantic relative to the Pacific, which is a situation analogous to modern conditions. Similarly, the apparent lack of $\delta^{13} \mathrm{C}$ difference between the equatorial Pacific and western North Atlantic sites from 26 to $33 \mathrm{Ma}$ in the Oligocene indicates reduced bottom-water formation analogous to NADW.

\section{Glacio-Eustacy and the $\delta^{18} \mathrm{O}$ Record}

What caused the major $\delta^{18} \mathrm{O}$ increases that occurred at about $36 \mathrm{Ma}$ (earliest Oligocene) and 29-30 Ma (near the early/middle Oligocene boundary)? Most isotopic studies have assumed that no significant continental ice existed prior to a $\delta^{18} \mathrm{O}$ increase of the middle Miocene (Shackleton and Kennett, 1975; Savin et al., 1975, 1981; Woodruff et al., 1981). However, Matthews and Poore (1980) suggested that significant ice volume may have existed prior to the middle Miocene. Miller and Fairbanks (1983) and Keigwin and Keller (1984) supported this by noting that bottom waters must have been as cold or colder than today if little or no ice was present in the Oligocene. High $\delta^{18} \mathrm{O}$ values $(>1.9 \%$ ) at about 36 and from 29 to $30 \mathrm{Ma}$ at Site 574 supply further evidence for ice volume at these times. Modern values for Cibicidoides at Site 574 would be $1.6 \%$, assuming an ice-free world (Graham et al., 1981; Shackleton and Kennett, 1975). Therefore, if the Oligocene were ice free, then bottom waters at Site 574 would have been $1-2^{\circ} \mathrm{C}$ colder than today during the earliest Oligocene and near the early/late Oligocene boundary. We believe that such cold bottom-water temperatures (and the inferred cold source region) are incompatible with an ice-free world and suggest that the $\delta^{18} \mathrm{O}$ increases resulted from a combination of ice-volume increases and bottom-water temperature drops.

Significant ice-volume increases would have resulted in a glacio-eustatic lowering of sea level. The covariance of planktonic and benthic foraminiferal $\delta^{18} \mathrm{O}$ is used in the Quaternary as an indicator of ice-volume changes (e.g., Shackleton and Opdyke, 1973). Keigwin (1980) and Keigwin and Keller (1984) noted approximately 0.3 and $0.4 \%$ covariance in planktonic and benthic foraminiferal $\delta^{18} \mathrm{O}$ increases for the earliest Oligocene and "middle" Oligocene, respectively. If it is assumed that 0.3 to $0.4 \%$ of the increases are attributable to ice-volume changes, sea level would have changed by 30 to $40 \mathrm{~m}$ (according to the Quaternary ice volume- $\delta^{18} \mathrm{O}$ calibration of Fairbanks and Matthews, 1978) in both the earliest and "middle" Oligocene.

Vail et al. (1977) and Vail and Mitchum (1980) noted that a major coastal offlap occurred in the "middle" Oligocene; they suggested that this was related to a major low stand of eustatic sea level. We estimate that the $\delta^{18} \mathrm{O}$ increase that occurred near the early/late Oligocene boundary at Sites 574 and 77 represents approximately 30 to $40 \mathrm{~m}$ of glacio-eustatic sea-level lowering. The maximum $\delta^{18} \mathrm{O}$ values at these sites (inferred minimum glacio-eustatic sea level) occurred in the upper part of undifferentiated Zone P21. The offlap event of Vail et al. (1977) and Vail and Mitchum (1980) occurred in Zone P21a at approximately $31 \mathrm{Ma}$ (time scale of Berggren et al., in press). Therefore, it apparently pre-dated the inferred age of the minimum glacio-eustatic sea level
( $=$ maximum $\delta^{18} \mathrm{O}$ values) which is estimated as 29 to $30 \mathrm{Ma}$. This offset of 1 to 2 m.y. is difficult to evaluate at present due to uncertainties in Oligocene biostratigraphy. If this difference is real, however, it may be resolved by noting that the inferred glacio-eustatic lowering may have begun prior to $30 \mathrm{Ma}$ (Fig. 2). Thus, the continental margin may not be responding directly to eustatic sea level, but rather to the rate of change of eustatic sea level (Pitman, 1978; Pitman and Golovchenko, 1983; Thorne and Watts, in press; Miller et al., 1985).

\section{CONCLUSIONS}

Two increases in benthic foraminiferal $\delta^{18} \mathrm{O}$ occurred in the Oligocene at Pacific Site 574: one at about $36 \mathrm{Ma}$ (earliest Oligocene) and the other at 29 to $30 \mathrm{Ma}$ (near the early/late Oligocene boundary). These increases are interpreted as having resulted from a combination of icevolume increases and bottom-water temperature drops.

The $\delta^{13} \mathrm{C}$ record at Site 574 provides evidence for two important conclusions. First, high $\delta^{13} \mathrm{C}$ values occurred in the early Oligocene, then decreased later in the Oligocene (after about $33 \mathrm{Ma}$ ). This pattern in benthic foraminifers has been noted in other Pacific, North Atlantic, and South Atlantic locations. The presence of a similar pattern in planktonic foraminifers (Shackleton et al., 1984; Miller and Fairbanks, in press) suggest that it resulted from global changes in the ${ }^{13} \mathrm{C}$ budget. Second, the Pacific was depleted in ${ }^{13} \mathrm{C}$ relative to the western North Atlantic from about 33 to $35 \mathrm{Ma}$ (within the early Oligocene) and from 26 to $18 \mathrm{Ma}$ (latest Oligocene to Miocene). Miller and Fairbanks (1983) noted a similar offset between $26 \mathrm{Ma}$ and $12 \mathrm{Ma}$ (latest Oligocene to Miocene). There was little $\delta^{13} \mathrm{C}$ difference between the Atlantic and Pacific from about 26 to $32 \mathrm{Ma}$ (late early to late Oligocene). This pattern suggests production of bottom water in the North Atlantic and/or its marginal seas (analogous to present-day NADW) during part of the early Oligocene ( 33 to $35 \mathrm{Ma}$ ) and latest Oligocene to Miocene ( 26 to $12 \mathrm{Ma}$ ) and reduction of production from 32 to $26 \mathrm{Ma}$.

Our $\delta^{13} \mathrm{C}$ comparisons involve only one Atlantic record and therefore must be considered tentative. In addition, coverage of the latest Oligocene at Sites 574 and 77 is limited at present. Further comparisons of Atlantic and Pacific abyssal benthic foraminiferal $\delta^{13} \mathrm{C}$ records are needed to demonstrate that the $\delta^{13} \mathrm{C}$ differences observed here reflect abyssal circulation changes.

\section{ACKNOWLEDGMENTS}

We thank W. B. Curry, R. G. Fairbanks, T. R. Janecek, L. D. Keigwin, W. F. Ruddiman, and N. J. Shackleton for reviewing the manuscript; R. G. Fairbanks for numerous discussions and use of the L-DGO mass spectrometer; W. B. Curry and L. D. Keigwin for discussions of $\delta^{13} \mathrm{C}$-abyssal circulation and $\delta^{18} \mathrm{O}$-ice volume relationships; and G. Kolibas for performing all isotopic analyses. L. D. Keigwin supplied data from Site 77. Samples were provided by DSDP. This research was supported by a postdoctoral fellowship from L-DGO, NSF Grant OCE 83-10086, and a grant from the ARCO Foundation (KGM).

This is Lamont-Doherty Geological Observatory Contribution number 3783 . E.T.'s research was partially funded by NSF grant OCE 83-10518.

\section{REFERENCES}

Arthur, M. A., Scholle, P. A., and Hasson, P., 1979. Stable isotopes of oxygen and carbon in carbonates from Sites 398 and 116 of the 
Deep Sea Drilling Project. In Sibuet, J.-C., Ryan, W. B. F., et al., Init. Repts. DSDP, 47, Pt. 2: Washington (U.S. Govt. Printing Office), 477-491.

Belanger, P. E., Curry, W. B., and Matthews, R. K., 1981. Core-top evaluation of benthic foraminiferal isotopic ratios for paleo-oceanographic interpretations. Palaeogeogr., Palaeoclimatol., Palaeoecol., 33:205-220.

Belanger, P. E., and Matthews, R. K., in press. The foraminiferal isotopic record across the Eocene/Oligocene boundary at Deep Sea Drilling Project Site 540. In Buffler, R. T., Schlager, W., et al., Init. Repts. DSDP, 77: Washington (U.S. Govt. Printing Office), 589-592.

Bender, M. L., and Keigwin, L. D., 1979. Speculations about the upper Miocene change in abyssal Pacific dissolved bicarbonate $\delta^{13} \mathrm{C}$. Earth Planet. Sci. Lett., 45:383-393.

Berger, W. H., 1970. Biogenous deep-sea sediments: fractionation by deep-sea circulation. Geol. Soc. Am. Bull., 81:1385-1402.

Berger, W. H., Vincent, E., and Thierstein, H. R., 1981. The deep-sea record: major steps in Cenozoic ocean evolution. In Warme, T. E., Douglas, R. C., and Winterer, E. L. (Eds.), The Deep-Sea Drilling Project: A Decade of Progress. Soc. Econ. Paleontol. Mineral. Spec. Publ., 32:489-504.

Berger, W. H., and Winterer, E. L., 1974. Plate stratigraphy and the fluctuating carbonate line. In Hsü, K. J., and Jenkyns, H. C. (Eds.), Pelagic Sediments on Land and Under the Sea. Int. Assoc. Sediment. Spec. Pub., 1:11-48.

Berggren, W. A., Kent, D. V., and Flynn, J., in press. Paleogene geochronology and chronostratigraphy. Geol. Soc. London Spec. Pub.

Blanc, P.-L., and Duplessy, J. C., 1982. The deep-water circulation during the Neogene and the impact of the Messinian salinity crisis. Deep Sea Res., 29A:1391-1414.

Blanc, P.-L., Rabussier, D., Vergnaud Grazzini, C., and Duplessy, J. C., 1980. North Atlantic deep water formed by the later middle Miocene. Nature (London), 283:553-555.

Broecker, W. S., 1982. Ocean chemistry during glacial time. Geochim. Cosmochim. Acta, 46:1689-1705.

Curry, W. B., and Lohmann, G. P., 1982. Carbon isotopic changes in benthic foraminifera from the western South Atlantic: reconstruction of glacial abyssal circulation patterns. Quat. Res. (NY), 18: 218-235.

1983. Reduced advection into Atlantic Ocean deep eastern basins during last glacial maximum. Nature (London), 306:577-580.

Duplessy, J.-C., Moyes, J., and Pujol, C., 1980. Deep water formation in the North Atlantic during the last ice age. Nature (London), 286:479-482.

Fairbanks, R. G., and Matthews, R. K., 1978. The marine oxygen isotopic record in Pleistocene coral, Barbados, West Indies. Quat. Res. (NY), 10:181-196.

Graham, D. W., Corliss, B. H., Bender, M. L., and Keigwin, L. D., 1981. Carbon and oxygen isotopic disequilibria of Recent benthic foraminifera. Mar. Micropaleontol., 6:483-497.

Haq, B. U., Worsley, T. R., Burkle, L. H., Douglas, R. G., Keigwin, L. D., Opdyke, N. D., Savin, S. M., Sommer, M. A., Vincent, E., and Woodruff, F., 1980. Late Miocene marine carbon isotopic shift and synchroneity of some phytoplanktonic biostratigraphic events. Geology, 8:437-431.

Hays, J. D., et al., 1972. Init. Repts. DSDP, 9: Washington (U.S. Govt. Printing Office).

Keigwin, L. D., 1979. Late Cenozoic stable isotopic stratigraphy and paleoceanography of DSDP sites from the east equatorial and central Pacific Ocean. Earth Planet. Sci. Lett., 45:361-382.

1980. Palaeoceanographic change in the Pacific at the Eocene-Oligocene boundary. Nature (London), 287:722-725.

Keigwin, L. D., and Keller, G., 1984. Middle Oligocene climatic change from equatorial Pacific DSDP Site 77. Geology, 12:16-19.

Keller, G., 1981. Miocene biochronology and paleoceanography of the North Pacific. Mar. Micropaleontol., 6:535-552.

Killingley, J. S., 1983. Effects of diagenetic recrystallization of ${ }^{18} \mathrm{O} /$ ${ }^{16} \mathrm{O}$ values of deep-sea sediments. Nature (London), 301:594-597.

Kroopnick, P., 1974. Correlation between ${ }^{13} \mathrm{C}$ and $\mathrm{CO}_{2}$ in surface waters and atmospheric $\mathrm{CO}_{2}$. Earth Planet. Sci. Lett., 22:397-403. 1980. The distribution of ${ }^{13} \mathrm{C}$ in the Atlantic Ocean. Earth Planet. Sci. Lett., 49:469-484.
Kroopnick, P., Weiss, R. F., and Craig, H., 1972. Total $\mathrm{CO}_{2},{ }^{13} \mathrm{C}$, and dissolved oxygen- ${ }^{18} \mathrm{O}$ at Geosecs II in the North Atlantic. Earth Planet. Sci. Lett., 16:103-110.

LaBrecque, J. L., Hsü, K. J., Carman, M. F., Jr., Karpoff, A. M., McKenzie, J. A., et al., 1983. Contributions to Paleogene stratigraphy in nomenclature, chronology, and sedimentation rates. $\mathrm{Pa}$ laeogeogr., Palaeoclimatol., Palaeoecol., 42:92-125.

Matthews, R. K., and Poore, R. Z., 1980. Tertiary $\delta^{18} \mathrm{O}$ record and glacio-eustatic sea-level fluctuations. Geology, 8:501-504.

Miller, K. G., Aubrey, M. P., Khan, M. J., Melillo, A. J., Kent, D. V., and Berggren, W. A., in press. Oligocene-Miocene biostratigraphy, magnetostratigraphy, and isotopic stratigraphy of the western North Atlantic. Geology.

Miller, K. G., and Curry, W. B., 1982. Eocene to Oligocene benthic foraminiferal isotopic record in the Bay of Biscay. Nature (London), 296:347-350.

Miller, K. G., Curry, W. B., and Ostermann, D. R., in press. Late Paleogene (Eocene to Oligocene) benthic foraminiferal oceanography of the Goban Spur Region, Deep Sea Drilling Project Leg 80. In Graciansky, P. C. de, Poag, C. W., et al., Init. Repts. DSDP, 80 , Pt. 1: Washington (U.S. Govt. Printing Office), 505-538.

Miller, K. G., and Fairbanks, R. G., 1983. Evidence for OligoceneMiddle Miocene abyssal circulation changes in the western North Atlantic. Nature (London), 306:250-253.

, in press. Oligocene-Miocene global carbon and abyssal circulation changes. In Sunquist, E., and Broecker, W. (Eds.), Chapman Conference on Natural Variations in Carbon Dioxide and the Carbon Cycle. Am. Geophys. Union Monograph Series.

Miller, K. G., Mountain, G. S., and Tucholke, B. E., 1985. Oligocene glacioeustasy and erosion on the margins of the North Atlantic. Geology, 13:10-13.

Oberhänsli, H., McKenzie, J., Toumarkine, M., and Weissert, H., 1984. A paleoclimatic and paleoceanographic record of the Paleogene in the central South Atlantic (Leg 73, Sites 522, 523, and 524). In Hsü, K. J., LaBrecque, J., et al., Init. Repts. DSDP, 73: Washington (U.S. Govt. Printing Office), 737-747.

Parsons, B., and Sclater, J. G., 1977. An analysis of the variation of ocean floor bathymetry and heat flow with age. J. Geophys. Res., 82:803-827.

Pitman, W. C., 1978. Relationship between eustacy and stratigraphic sequences of passive margins. Geol. Soc. Am. Bull., 89:1389-1403.

Pitman, W. C., and Golovchenko, X., 1983. The effect of sea-level change on the shelf edge and slope of passive margins. Soc. Econ. Paleontol. Min. Spec. Pub., 33:41-58.

Poore, R. Z., and Matthews, R. K., 1984. Late Eocene-Oligocene oxygen- and carbon-isotope record from South Atlantic Ocean, Deep Sea Drilling Project Site 522. In Hsü, K. J., LaBrecque, J. L., et al., Init. Rept. DSDP, 73: Washington (U.S. Govt. Printing Office), 725-735.

Savin, S. M., 1977. The history of the earth's surface temperature during the last 100 million years. Annu. Rev. Earth Planet. Sci., 5: 319-355.

Savin, S. M., Douglas, R. G., Keller, G., Killingley, J. S., Shaughnessy, L., Sommer, M. A., Vincent, E., and Woodruff, F., 1891. Miocene benthic foraminiferal isotope records: a synthesis. Mar. Micropaleontol., 6:423-450.

Savin, S. M., Douglas, R. G., and Stehli, F. G., 1975. Tertiary marine paleotemperatures. Geol. Soc. Am. Bull., 86:1499-1510.

Sclater, J. G., Abbott, D., and Thiede, J., 1977. Paleobathymetry of sediments of the Indian Ocean. In Heirtzler, J. R., Bolli, H. M., and Davies, T. A. (Eds.), Indian Ocean Geology and Biostratigraphy: Washington (Am. Geophys. Union), 25-59.

Sclater, J. G., Anderson, R. N., and Bell, N. L., 1971. Elevation of ridges and the evolution of the central eastern Pacific. J. Geophys. Res., 76:7888-7915.

Shackleton, N. J., 1977. Carbon-13 in Uvigerina: tropical rain forest history and the equatorial Pacific carbonate dissolution cycles. In Anderson, N. R., and Malahoff, A. (Eds.), The Fate of Fossil Fuel $\mathrm{CO}_{2}$ in the Oceans. New York (Plenum Press), 401-427.

Shackleton, N. J., Hall, M. A., and Boersma, A., 1984. Oxygen and carbon isotope data from Leg 74 foraminifers. In Moore, T. C., Jr., Rabinowitz, P. D., et al., Init. Repts. DSDP, 74: Washington (U.S. Govt. Printing Office), 599-612. 
Shackleton, N. J., and Kennett, J. P., 1975. Paleotemperature history of the Cenozoic and the initiation of Antarctic glaciation: oxygen and carbon isotopic analyses in DSDP Sites 277,279 , and 281 . In Kennett, J. P., Houtz, R. E., et al., Init. Repts. DSDP, 29: Washington (U.S. Govt. Printing Office), 743-755.

Shackleton, N. J., and Opdyke, N. D., 1973. Oxygen isotopic and palaeomagnetic stratigraphy of equatorial Pacific Core V28-238: oxygen isotope temperatures and ice volume on a $10^{5}$ and $10^{6}$ year scale. Quat. Res. (NY), 3:39-55.

Snyder, S. W., Müller, C., and Miller, K. G., 1984. Biostratigraphy and paleoceanography across the Eocene/Oligocene boundary at Deep Sea Drilling Project Site 549. Geology, 12:112-115.

Thorne, J., and Watts, A. B., in press. Seismic reflectors and unconformities at passive continental margins. Nature (London).

Tjalsma, R. C., and Lohmann, G. P., 1983. Paleocene-Eocene bathyal and abyssal benthic foraminifera from the Atlantic Ocean. Micropaleontology Press Spec. Pub. 4.

Tucholke, B. E., and Vogt, P. R., 1979. Western North Atlantic: sedimentary evolution and aspects of tectonic history. In Tucholke, B. E., Vogt, P. R., et al., Init. Rept. DSDP, 43: Washington (U.S. Govt. Printing Office), 791-825.

Vail, P. R., and Mitchum, R. M., 1980. Global cycles of sea-level change and their role in exploration. Proc. Tenth World Petrol. Congress, 2, Expl. Supply and Demand, pp. 95-104.
Vail, P. R., Mitchum, R. M., Jr., Todd, R. G., Widmier, J. M., Thompson, S. III, Sangree, J. B., Bubb, J. N., and Hatelid, W. G., 1977. Seismic stratigraphy and global changes of sea level. In Payton, C. E. (Ed.), Seismic Stratigraphy-Applications to Hydrocarbon Exploration. Am. Assoc. Petrol. Geol. Mem., 26:49-205.

Vincent, E., Killingley, J., and Berger, W. H., 1980. The magnetic epoch 6 carbon shift: a change in the ocean's ${ }^{13} \mathrm{C} /{ }^{12} \mathrm{C}$ ratio 6.2 million years ago. Mar. Micropaleontol., 5:185-203.

Wood, K. C., Miller, K. G., and Lohmann, G. P., in press. Middle Eocene to Oligocene benthic foraminifera from the Oceanic Formation, Barbados. Micropaleontology.

Woodruff, F., Savin, S. M., and Douglas, R. G., 1980. Biological fractionation of oxygen and carbon isotopes by Recent benthic foraminifera. Mar. Micropaleontol., 5:3-13.

1981. Miocene stable isotopic record: a detailed deep Pacific ocean study and its paleoclimatic implications. Science (Washington, D. C.), 212:665-668.

Date of Initial Receipt: 14 November 1983

Date of Acceptance: 12 March 1984 